\title{
DETERMINANTS OF INNOVATION IN EUROPEAN CONSTRUCTION FIRMS
}

\author{
José M. BARATA ${ }^{\mathrm{a}}$, Elsa FONTAINHA ${ }^{\mathrm{b}}$ \\ ${ }^{a}$ SOCIUS - Research Centre, ISEG, Lisbon School of Economics and Management, Economics \\ Department, Universidade de Lisboa, Rua do Quelhas, 6 1200-781, Lisboa, Portugal \\ ${ }^{b} I S E G$, Lisbon School of Economics and Management, Economics Department, \\ Universidade de Lisboa, Rua do Quelhas, 6 1200-781, Lisboa, Portugal
}

Received 24 February 2014; accepted 24 January 2015

\begin{abstract}
The research aims to identify the determinants of process and product innovation in a traditional and low-tech sector, supported in micro, small and medium-sized enterprises (SMEs), specifically European Construction Sector. The study uses micro data from the e-Business Survey of the European Commission. The dependent variables studied are binary (presence or absence of process or/and product innovation). The explanatory variables considered are: suppliers, clients, market orientation, turnover growth and size. In addition, some national context variables - GDP per capita and R\&D weight in GDP - are also tested. The results show that the sector of construction innovates, and the factors that contribute more to this innovation are suppliers and growth of business. It is also concluded that firm size is more relevant for process innovation than for product innovation, and companies that are guided by international markets innovate more than those that focus on local and regional markets.
\end{abstract}

Keywords: innovation determinants, construction sector, SME, process innovation, product innovation, Europe.

JEL Classification: L74, O31, O52.

\section{Introduction}

The driving force for economic development is innovation. Through innovation, in the sense of increasing profits, entrepreneurs alter the stability of businesses, turning it into economic growth (Schumpeter 1942). The goal of this research is to study the determinants of innovation (see Bhattacharya, Bloch 2004; OECD 2005; Vaona, Pianta 2008; Ahuja et al. 2008; Dodgson et al. 2014) in a traditional sector with a high contribution of micro and small enterprises, specifically European Construction Sector.

Corresponding author José M. Barata

E-mail: jmbarata@iseg.ulisboa.pt 
The main motivation underlying this article stems from the perceived necessity to extend the studies on innovation to industries outside the oft analysed leading "high-tech" manufacturing industry. In this case, the construction sector is located at the intersection of the manufacturing industry, creative industries and services industries. It is a traditional SME based industry, with an undeniable economic and social impact.

Reichstein et al. (2008: 601) rightly argue that "because it [the construction sector] produces the capital goods - buildings and structures - to enable other sectors to develop", it is imperative to understand the sources of innovation for innovation strategy and policy to improve performance within the sector. We agree that construction firms do innovate. Small construction firms are able to deliver complex projects for diverse types of clients in a creative way and under pressure. In fact, the construction sector has experienced knowledge intensification through an expansion of, for instance, "knowledge intensive business firms". Moreover, it is important to stress that "innovation in construction is in many ways 'hidden' from the usual metrics applied to technology-driven sectors" (Reichstein et al. 2008: 604. See also Gault 2013).

The study uses micro data from the e-Business Survey of the European Commission, which includes data for construction firms $(\mathrm{N}=2,654)$ from 27 countries in Europe, as well as for other sectors (14,065 firms). The dependent variables studied are binary (presence or absence of process or/and product innovation), so a Probit model was applied.

The paper, after this introduction, will present the main concepts and models of innovation underlying the theoretical framework of this research, as well as a brief note on the construction industry in Europe; the first section ends with a summary on the determinants of innovation in the construction sector. In the second section, we will present the data and the methodology followed. The last two sections (Sections 3 and 4) are reserved, on the one hand, to the presentation and discussion of results, and on the other, to synthesize the general conclusions and the suggestions for future research.

\section{Innovation and the construction sector in Europe}

The next section will focus on the relevant concepts of innovation and models of innovation - the central concept of this paper - making a small extension toward the linkage between innovation and cooperation. After that presentation, we will propose a brief synthesis on the main characteristics of construction sector in Europe. Finally, the determinants of innovation in the construction sector will be addressed.

\subsection{Concepts and models of innovation: a synthesis}

As the fundamental dynamic of the new paradigm for the competitiveness of firms and nations, innovation must be considered as a "process", thus counteracting the view of innovation as a static or epiphenomenal event (Lundvall 1988: 350).

The definition of what "innovation" is immediately results in a series of important questions whose answers differ according to the available indicators and the proposed aims. Most definitions associate the concept with the technological aspects of the introduction 
of new (or better) products or processes. However, other more general interpretations have been developed. These may include, for example, any organizational and managerial changes that may have taken place, and thus go far beyond the more limited analysis normally undertaken at the level of equipment, systems and devices.

The concept of innovation adopted in this study results from a synthesis of the relevant literature (see, for example: Kline, Rosenberg 1986; Freeman, Soete 1997; Salter, Alexy 2014) and the definitions proposed by international bodies, such as the Organization of Economic Cooperation and Development (OECD 2005). Two fundamental areas of innovation are considered in this paper: innovation in "products" and innovation in "processes".

According to Marques, Barata (2006: 114), a product is regarded as technologically innovative when it displays a substantial difference in the materials or components used, or when it is designed for new uses. Innovation may refer to either an entirely new product (radical innovation) or improvements to a product (incremental innovation). Products that are considered innovative may be so at world level, at national or industry level, or merely at the firm level.

A process is regarded as technologically innovative when it is used either for the production of new or improved products or for the manufacture of products which were previously made by the firm but now require new techniques or the same techniques performed in a more effective manner. Here a distinction is also drawn between "new" and "improved" processes.

These different specifications of innovation, its dynamics, economic and social impact (radical versus incremental innovation) and the difficulties of an empirical approach point to the complexity of the phenomenon and its determinants.

When considered as a process, innovation consists of a series of steps that are scientific, technical, commercial, and financial in nature. Thus, $R \& D$ is just one of these steps, and $R \& D$ activities and non-R\&D activities, together forming the "innovative activities", are the central aspects of the surveys on innovation, namely, the Community Innovation Surveys (CIS) (OECD 2005). Non-R\&D activities consist of design, projects, engineering, tests, acquisition of non-incorporated technology (patents, technological know-how, etc.) and the acquisition of incorporated technology (machinery, equipment, etc.) (Barata 2005). It is these non-R\&D activities that are the main object of our analysis in this paper. The next synthesis on "models of innovation" complements the presentation of the theoretical framework of this research.

Over the last few decades, our thinking about science, technology and innovation has been accompanied by the linear conception of the "Research-Development-Production-Market" type (Rothwell 1992a, 1992b). Until the mid-1960s, the dominant perception of the innovation process consisted of a pure form of linear "technology-push" innovation (Schumpeter 1942 - based on "supply" of science and technology). It was assumed that there was a continuous progression from scientific discovery to the appearance of new products and processes on the market ("first generation"). In the second half of the 1960s, as a result of more in depth research, greater importance began to be attached to the role of the market in the innovation process. This fact led to the emergence of a linear demand-pull ("second generation") conception of innovation (Schmookler 1966 - "demand"-led innovation). 
During the 1970s, the most systematic study of the phenomenon - namely about the success factors of innovation - showed that the earlier conceptions of innovation, when taken individually, were only extreme simplifications and very particular cases of a more general process of confluence/coupling between science, technology and the market ("third generation"). Notwithstanding, in this conception of innovation, there remains essentially a sequential understanding of the innovation process.

Only in the course of the 1980s were the first truly integrated models proposed. The "chain-linked" innovation model (Kline, Rosenberg 1986) is just one example in which innovation is conceived as an integrated process. The integrated models of the innovation process ("fourth generation") (Rothwell 1992a, 1992b) are characterized not only by their interfunctional integration, but also by their ever greater integration with the scientific and technological system and by their vertical and horizontal integration with other firms (suppliers, clients, competitors).

The idealized development of this fourth-generation integrated model - the "fifth-generation" model for the 1990s and for the beginning of the present century - will be characterized by the existence of systems integration and networking (SIN) (Rothwell 1992a, 1992b). This presupposes a fully integrated parallel development: links with clients, strategic integration with suppliers, strategies based on time and an emphasis on flexibility, quality and other extra-price factors. The strategies of access to "complementary assets" (Teece 1986) and the implementation of "inter-organisational information systems" are valuable supports for this new conception of the innovation process (Marques, Barata 2006). This last vision provides an agenda for a greater "opening" up of the innovation process. This is the general theoretical background for the present paper.

Given the dynamism and density of present business environment, it is essential to complement the enterprise's internal knowledge and expertise with external sources. Even major organizations require knowledge beyond their boundaries in order to develop their innovations. Also, external sources have high significance to small and medium-sized firms (Rothwell 1992a, 1992b; Malecki, Tootle 1996). According to the "open innovation model", firms need to open their boundaries to external partners (Chesbrough 2003; Spithoven et al. 2011). The innovation process may involve external sources from different origins: clients, suppliers, universities, competitors, and other agents (D'Este et al. 2012; Lasagni 2012).

In general, authors have demonstrated that cooperation with other agents from outside the enterprise constitute a significant resource in actual competitive framework, especially in the development of new products and processes and learning capabilities. It also allows to share expenses and uncertainty, exploit synergies, scale and scope economies, as well as benefit from government support (Sampson 2007; Becker, Dietz 2004).

The measurement of the process of innovation is critical for both practitioners and academics (Gault 2013). In fact, a significant number of empirical analysis set out, firstly, the main determinants of both innovation inputs (the innovation effort) and innovation outputs (the results of innovation dynamics); secondly, the researchers develop an analysis on the relationship between inputs, outputs and economic and financial performance (Kleinknecht, Mohnen 2002; Marques, Barata 2006; Bontempi, Mairesse 2015) - "the innovation function". 


\subsection{The construction sector in Europe}

The European Construction sector, in broad terms, "Building" and "Civil Engineering"1 is important in all European countries, despite the recent crisis (Kaklauskas et al. 2011) (Table 1).

Table 1. Construction Value Added as a percentage of Gross Domestic Product European Union

\begin{tabular}{|c|c|c|c|c|c|}
\hline & 2005 & 2007 & 2009 & 2011 & 2012 \\
\hline European Union (28 countries) & : & $:$ & : & 3.9 & 3.8 \\
\hline European Union (27 countries) & 5.0 & 5.0 & 4.3 & 3.9 & \\
\hline Belgium & 3.8 & 3.9 & 4.2 & 4.3 & 4.2 \\
\hline Bulgaria & 3.6 & 5.9 & 6.4 & 3.4 & 3.1 \\
\hline Czech Republic & 4.9 & 4.8 & 4.7 & 4.2 & 3.9 \\
\hline Denmark & 4.6 & 5.0 & 4.1 & 3.6 & 3.6 \\
\hline Germany & 2.7 & 2.5 & 2.6 & 2.9 & 3.0 \\
\hline Estonia & 6.6 & 7.4 & 4.3 & 4.4 & 5.2 \\
\hline Ireland & 2.2 & 2.3 & 5.6 & 2.1 & $:$ \\
\hline Greece & $:$ & $:$ & 1.8 & 1.9 & 2.3 \\
\hline Spain & 13.3 & 12.0 & 7.5 & 4.7 & 3.9 \\
\hline France & 4.2 & 4.4 & 4.4 & 4.4 & 4.3 \\
\hline Croatia & $:$ & $:$ & 6.3 & 3.9 & 3.3 \\
\hline Italy & 4.3 & 4.7 & 3.9 & 3.7 & 3.4 \\
\hline Cyprus & 12.5 & 12.7 & 10.2 & 7.1 & 5.7 \\
\hline Latvia & 5.6 & 7.5 & 3.3 & 2.8 & 3.4 \\
\hline Lithuania & 5.1 & 6.9 & 2.8 & 2.7 & 2.9 \\
\hline Luxembourg & 6.0 & 5.3 & 5.5 & 4.7 & 4.9 \\
\hline Hungary & 3.1 & 2.9 & 2.8 & 2.4 & 2.3 \\
\hline Malta & $:$ & $:$ & 3.6 & 3.8 & 3.8 \\
\hline Netherlands & 5.0 & 4.9 & 4.9 & 4.6 & 4.2 \\
\hline Austria & 5.2 & 5.2 & 5.1 & 4.8 & 4.9 \\
\hline Poland & 3.8 & 5.5 & 4.9 & 4.6 & 3.5 \\
\hline Portugal & 6.0 & 5.9 & 5.6 & 4.2 & 3.5 \\
\hline Romania & 3.3 & 4.4 & 4.4 & 3.5 & 3.2 \\
\hline Slovenia & 4.3 & 5.3 & 4.9 & 3.6 & 3.5 \\
\hline Slovakia & 2.4 & 2.2 & 2.1 & 3.4 & 3.5 \\
\hline Finland & 4.4 & 4.5 & 4.8 & 4.6 & 4.9 \\
\hline United Kingdom & 6.0 & 6.0 & 4.9 & 4.5 & 4.6 \\
\hline : not available & & & & & \\
\hline
\end{tabular}

Source: authors' computation based on Eurostat 2015a, 2015b.

${ }^{1}$ The civil engineering (public works) represent an important share in the Construction sector and has a specific dynamic (Gramlich 1994). 
Construction activities in the EU-28 provided employment to an estimated 13.0 million persons in 2011 (some $9.7 \%$ of the non-financial business economy workforce), and generated an estimated EUR 501 billion of value added (8.1\% of the non-financial business economy's total value added). There were an estimated 3.3 million construction enterprises across the EU-28, which generated an estimated EUR 1,566 billion in turnover (Eurostat 2015b).

The construction sector is characterized by a high number of small enterprises (local markets), and relatively few large ones. Micro and small enterprises (with less than 50 persons employed) together accounted for $73.2 \%$ of the EU-28 construction sector workforce in 2011. These enterprises also provided about two thirds (65.9\%) of industry value added in 2011, compared with two fifths (39.5\%) for the whole of the non-financial business economy (Eurostat 2015a).

The construction sector observes cyclical patterns in its development. Nonetheless, it is of strategic importance to the EU as it delivers the buildings and infrastructure needed by the rest of the economy and society. Last but not least, we should also stress the well-known capacity of the construction sector in job creation and its significant upstream (intensive user of materials) and downstream economic effects (real estate services, marketing services), notwithstanding its status of non-transactionable goods industry ${ }^{2}$.

The long and deep downturn in construction activity was widespread within the EU-27. After stabilising in 2010, a second downturn started in the third quarter of 2011 and has not yet shown signs of stabilization (by the end of 2012). However, "future competitiveness strategies for the construction sector could be the key to environmental and social challenges in the EU [...]" (European Commission 2012b: 78).

\subsection{Innovation in the construction sector: determinants of innovation}

Construction sector is classified as a low-tech sector (European Commission 2012a). However, low-tech and high-tech industries interconnect (as partners, clients, buyers) and both contribute to innovation (Pavitt 1984; Bhattacharya, Bloch 2004; Brochner 2010; Hansen, Winther 2011; Loosemore 2014). The study by Reichstein et al. (2008) for the construction sector in the UK indicates several examples of product and process innovation in the construction industry, shown in Table 2. Skibniewski and Zavadskas (2013) survey the literature and identify the trends (current and for last two decades) in the development of civil engineering and construction technologies stressing the environmental and energy issues associated to present construction sector.

In the literature on innovation in the construction sector, several factors have been identified as explaining innovation. Vendors are considered a very important source in stimulating innovation, because they are a key channel for obtaining relevant information, equipment and materials. Therefore, a close relationship with suppliers is essential for the company to innovate its products and processes. Reichstein et al. $(2005,2008)$ present explanatory factors of innovation in the sector, among which they highlight the importance

\footnotetext{
${ }^{2}$ For instance, onsite construction (NACE section F) consumed $€ 750 \mathrm{bn}$ of intermediate products from other sectors than construction in a broad sense (NACE sections $\mathrm{C}$ to $\mathrm{K}$ minus J), corresponding to roughly $44 \%$ of the subsector's turnover (European Commission 2012b, 2012c).
} 
of suppliers as providing the most evidence for establishing a direct relationship with innovation. Bogers and Lhuillery (2011) state that manufacturing is important as an absorber of supplier knowledge for product innovation, and of competitor knowledge for process innovation. Zavadskas et al. (2011) stress the diverse innovation sources across the life cycle of a construction project: "An enormous volume of construction innovation knowledge is generated during the phases of brief, design, planning, construction, maintenance, facilities management, demolition and utilisation of a facility" (Zavadskas et al. 2011: 15). The sector characteristics and problems promote those innovations. For example, for the project management specific methodologies are developed (Zavadskas et al. 2014).

Customers also play a role in the innovation of a company, and prolonged contact with customers gives rise to innovation (Lundvall 1985, 1988; Reichstein et al. 2008; Bygballe, Ingemansson 2014). Tykka et al. (2010) conclude that the factor that promotes innovation in timber framed firms in the construction sector is business opportunities related to demographic growth in the firm location area. This sector places great importance on specifications given by customers, and in an increasingly competitive market, this issue also becomes more important. Bygballe and Ingemansson (2014) based on two studies of innovation in the Swedish and Norwegian construction industries, concluded that costumers are important driving forces of innovation.

Firm size is found to be more relevant to process innovation than product innovation. With regard to process innovation, larger firms innovate more than small ones because the former feature production or organizational processes that are much more complex, where innovation is almost imperative for simplification (Pavitt 2002; Reichstein et al. 2005, 2008; Vaona, Pianta 2008; Fontainha 2010; Fontainha et al. 2014). Small construction firms, contrasting with large companies, try a strong and close connection with clients, the owner has a relevant role, and they focus on niche markets (Barrett, Sexton 2006).

Table 2. Examples of product and process innovation in the construction sector

\begin{tabular}{|c|c|}
\hline Examples of product innovation & Examples of process innovation \\
\hline $\begin{array}{l}\text { - Development of a composite fire door } \\
\text { - Lancing table for improved heat exchange } \\
\text { cleaning process } \\
\text { - Conditioning and monitoring systems for } \\
\text { railway points system } \\
\text { - External solar shading to new buildings } \\
\text { - Square dill bits - new advanced mains boards } \\
\text { - Development of "sobo" system for a specific } \\
\text { application in manufacturing industry } \\
\text { - Multiple temperature cabinet built into wall and } \\
\text { house to receive house delivery } \\
\text { - Installation of new structural lining within failed } \\
\text { underground structure } \\
\text { - Implementing lean manufacturing quality } \\
\text { procedures in construction } \\
\text { - Design and construction of welding machine }\end{array}$ & $\begin{array}{l}\text { - Electronic communications with clients for } \\
\text { exchange of data } \\
\text { - CAD and electronic data links with some } \\
\text { of our customers } \\
\text { - Automatic delivery of concrete } \\
\text { - Establishment of intranet for knowledge } \\
\text { exchange etc. } \\
\text { - More modern woodworking machinery } \\
\text { - Computerised systems - computerised } \\
\text { timesheets stock control } \\
\text { - Work identification and control processes } \\
\text { - Asset based-maintenance management } \\
\text { - Direct cost control system with integrated } \\
\text { design, buying, invoicing, processing } \\
\text { - We introduced a new manufacturing line also } \\
\text { manufactured more components in-house }\end{array}$ \\
\hline
\end{tabular}

Source: 3rd UK Innovation Survey, 2001 as presented by Reichstein et al. (2008: 612). 
The way companies behave before the markets where they operate - the market orientation - is also strongly linked to the level of innovation of products and processes. Companies with local or regional perspectives have a lower propensity to innovate than firms with national or international objectives, insofar as the latter are exposed to strong external competition (Reichstein et al. 2008).

Regulation of the sector was considered by Gann et al. (1998) as a key creator of obstacles to innovation (e.g. safety and environmental legislation). Nevertheless, this idea has since been contradicted by Reichstein et al. (2008), who argue that there is no statistically significant relationship between regulation of the sector and the innovation of products and processes: "The role of regulations as a source of innovation appears to have no part in shaping the potential of becoming a process or product innovator" (Reichstein et al. 2008: 617). Still, regulation should be considered a very important factor, and one that companies should take into consideration when making decisions about their activities. Based on empirical studies, Noailly (2012) and Testa et al. (2011) conclude that environmental regulation (direct regulation, economic instruments and soft instruments) is responsible for investments in advanced technological equipment and product innovation. Zutshi and Creed (2015) discuss some of the challenges that construction firms across the world have when implement and certify the environmental management systems.

There is also a difficulty in measurement (Gambatese, Hallowell 2011). The underestimation of spending on Research and Development (R\&D) (see, in general, Silverberg, Soete 1994; Gault 2013) is also a factor that limits knowledge of innovation in the sector. Few construction companies have a R\&D Department, and spending on R\&D is not completely matched by statistics. A second reason for the underestimation of R\&D in this sector is that innovation in construction depends heavily on the progress made by its suppliers of materials and other components and projects (Pavitt 1984; Hall 1994) and the departments of R\&D in upstream sectors (e.g. architects or materials innovation departments) (Reichstein et al. 2008; Arora et al. 2014; Loosemore 2014).

Another important aspect is that the final product is often unique, because usually its production is by project and project-based companies (Gambatese, Hallowell 2011). This uniqueness is another distinguishing feature of the sector. Furthermore, the performance of tasks is often subject to adverse weather conditions, for example work takes place outdoors in different seasons thereby limiting the use of some materials (De Place Hansen, Larsen 2011). These characteristics may also contribute to or impede innovation.

The construction sector has also some characteristics that are distinct from other sectors, specifically in its products and processes, which limit or inhibit innovation (Nam, Tatum 1988). The construction sector is dominated by small companies, which, therefore, are more difficult to organize, and less likely to be innovative because they have less financial and technical capabilities and ability to raise capital (Damanpour 2010). Several players in the market are also involved. For example, planners, contractors, subcontractors and suppliers are usually involved in all stages of the process (Paulson 1995; see also Porter, Stern 2001). Given that the product of the sector is located in a certain geographic area, and therefore not able to be moved, a characteristic that hampers innovation is the immobility of the final product. In addition, the fact that the product has a long cycle life (approximately 30 years) affects innovation adversely (Gramlich 1994). Nam and Tatum (1988) 
called this feature set a "locked system", claiming that it was responsible for construction companies' difficulty in innovating (Reichstein et al. 2008).

Summing up, the literature on the economics and management of construction industry suggests several potential determinants of innovation (Reichstein et al. 2008):

1. Relationships with customers and suppliers might be expected to support innovation dynamics;

2. Size should empower firms to innovate, by freeing them from the "liabilities of smallness" (namely, lack of scale economies) and "newness" (for instance, absence of business "routines") in the sense of Nam and Tatum (1988);

3. Local market orientation may deter innovativeness;

4. Regulations may support innovation by encouraging the use of new practices and products;

5. R\&D expenditures should, mainly, support the capture of external knowledge;

In this paper, the first three determinants of innovation will be essayed.

\section{Data and methodology}

\subsection{Data}

The empirical study uses micro data from the e-Business Survey of the European Commission (European Commission 2006), which includes data for construction firms $(\mathrm{N}=$ $2,654)^{3}$ from 27 countries in Europe, as well as for other sectors $(\mathrm{N}=14,065)$. Table 3, Table 4 and Figure 1 show the distribution of product and process innovation in the sample of construction firms. About one quarter of the firms in the construction sector innovate (Table 3), innovation increases with size (Table 4) and the construction sector shows one of the lowest levels of innovation (Fig. 1). Some factors purported to limit innovation in the construction sector (Nam, Tatum 1988; Gann et al. 1998) do not, in fact, prevent innovation, particularly in larger and growing companies.

Table 3. Product and process innovation in construction firms

\begin{tabular}{cccccccc}
\hline Product innovation & $\mathrm{N}$ & $\%$ & Valid $\%$ & Process Innovation & $\mathrm{N}$ & Valid \% & $\%$ \\
\hline Yes & 624 & 23.5 & 24.2 & Yes & 665 & 25.7 & 25.1 \\
\hline No & 1955 & 73.7 & 75.8 & No & 1922 & 74.3 & 72.4 \\
\hline n.a. & 75 & 2.8 & & n.a. & 67 & & 2.5 \\
\hline Total & 2654 & 100 & 100 & Total & 2654 & 100 & 100 \\
\hline
\end{tabular}

Note: n.a. $=$ missing values.

Source: authors' computation based on e-Business Survey 2006 micro database.

\footnotetext{
${ }^{3}$ The sample of Construction firms is distributed by the following subsectors: NACE 4521 General construction of buildings and civil engineering works $(\mathrm{N}=1348)$; NACE 4523 Construction of motorways, roads, airfields and sport facilities $(\mathrm{N}=202)$; NACE 4524 Construction of water projects $(\mathrm{N}=41)$; NACE 4531 Installation of electrical wiring and fittings $(\mathrm{N}=552)$; NACE 4532 Insulation work activities $(\mathrm{N}=62)$; and NACE 4533 Plumbing $(\mathrm{N}=449)$. The survey interviews were conducted in March and April 2006, using computer-aided telephone interview (CATI), the fieldwork was coordinated by Ipsos (Germany) in cooperation with its national organizations.
} 
Table 4. Product and process innovation by firm size

\begin{tabular}{lcccc}
\hline \multicolumn{1}{c}{ Size group $^{(\mathrm{a})}$} & $\mathrm{N}$ & $\%$ & Product innovation & Process innovation \\
\hline Micro (1-9) & 881 & 38.2 & $20.6 \%$ & $18.2 \%$ \\
\hline Small (10-49) & 740 & 32.1 & $21.8 \%$ & $24.8 \%$ \\
\hline Medium (50-249) & 588 & 25.5 & $24.3 \%$ & $31.2 \%$ \\
\hline Large (250+) & 97 & 4.2 & $38.7 \%$ & $46.7 \%$ \\
\hline Total & 2306 & 100 & &
\end{tabular}

Note: (a) Size categories according the number of employees (European Commission 2003). Source: authors' computation based on e-Business Survey 2006 micro database.

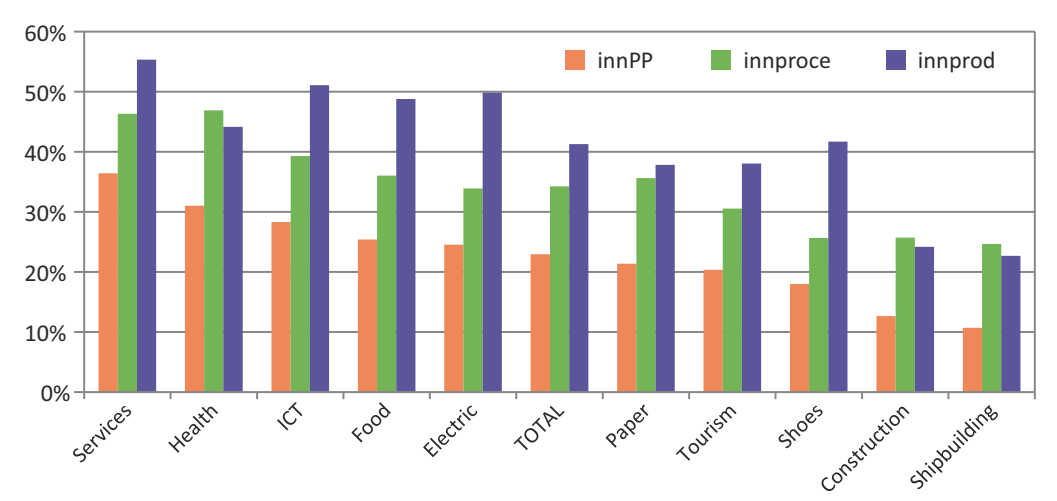

Fig. 1. Innovation by firm sector $(\mathrm{N}=14,065)$

Notes: innPP $=$ product and process innovation; innproce $=$ process innovation; innprod $=$ product innovation.

Source: authors' computation based on e-Business Survey 2006 micro database.

\subsection{Modelling the determinants of process and product innovation in Construction sector}

Table 5 describes the dependent variables and the explanatory variables, and Table 6 summarizes the descriptive statistics of these variables. Some of the estimation results of the models are shown in Tables 7 to 9. The discussion of the results is made in the next section. Several models were tested to explain the product innovation and process innovation (Appendix). The specification of each model differs mainly by replacing the regional market variable by national or international market variable and the inclusion (or not) of the two contextual variables (Gross Domestic Product - GDP - per capita and R\&D weight in GDP) (see Hartmann 2006). The Models 5 to 7 adopt similar specifications to those of Models 1 to 4 models, but the dependent variable is both product and process innovation. Models 8 and 9 are applied to sub-samples related to firm size.

Next, we will add some brief explanation for the variables selected. Following the seminal works of Schumpeter, the relationship of size with innovation (product and process) is expected to be positive (Vaona, Pianta 2008). Putting this hypothesis in Reichstein et al. (2008) terms, it can be expected that smaller firms will be less likely to innovate than large firms. 
Table 5. Variable description

\begin{tabular}{|c|c|}
\hline \multicolumn{2}{|r|}{ Dependent variables } \\
\hline $\begin{array}{l}\text { Product innovation } \\
\text { innprod }\end{array}$ & $\begin{array}{l}=1 \text { if the firm introduced a new product or a large improvement } \\
\text { in a product (service) during the year before the survey, } 0 \\
\text { otherwise }\end{array}$ \\
\hline $\begin{array}{l}\text { Process innovation } \\
\text { Innproce }\end{array}$ & $\begin{array}{l}=1 \text { if the firm introduced a new process or a large improvement } \\
\text { in a process during the year before the survey, } 0 \text { otherwise }\end{array}$ \\
\hline $\begin{array}{l}\text { Product and process innovation } \\
\text { innovPP }\end{array}$ & $\begin{array}{l}=1 \text { if innprod and innproce occurred simultaneously in the year } \\
\text { before the survey, } 0 \text { otherwise }\end{array}$ \\
\hline \multicolumn{2}{|r|}{ Independent variables } \\
\hline $\begin{array}{l}\text { Firm size } \\
\text { size }\end{array}$ & $\begin{array}{l}\text { Size according the number of employees: } 1 \text { if (1-9), } 2 \text { if (10-49), } \\
3 \text { if (50-249) and } 4 \text { if ( } 250 \text { or more) }\end{array}$ \\
\hline $\begin{array}{l}\text { Large firms } \\
\text { large }\end{array}$ & $=1$ if the firm has size $4($ size $=4), 0$ if $(\text { size }=3)^{*}$ \\
\hline $\begin{array}{l}\text { Regional clients } \\
\text { mk_regional }\end{array}$ & $=1$ if clients are regional, 0 otherwise \\
\hline $\begin{array}{l}\text { National clients } \\
\text { mk_national }\end{array}$ & $=1$ if the clients are national/domestic, 0 otherwise \\
\hline $\begin{array}{l}\text { Clients } \\
\text { client }\end{array}$ & $=1$ if the clients have expectations about innovation, 0 otherwise \\
\hline $\begin{array}{l}\text { Suppliers } \\
\text { supplier }\end{array}$ & $\begin{array}{l}=1 \text { if the suppliers have expectations about innovation, } \\
0 \text { otherwise }\end{array}$ \\
\hline $\begin{array}{l}\text { Business growth } \\
\text { gsales }\end{array}$ & $=1$ if the firm increased sales, 0 otherwise \\
\hline $\begin{array}{l}\text { Leader as goal } \\
\text { leader }\end{array}$ & $=1$ if the firm wants to be leader, 0 otherwise \\
\hline $\begin{array}{l}\text { Follower as goal } \\
\text { follower }\end{array}$ & $=1$ if the firm wants to be follower, 0 otherwise \\
\hline $\begin{array}{l}\text { Macroeconomic context } \\
\text { GDPpc }\end{array}$ & GDP per capita in each country (average value of 2004/05/06) \\
\hline $\begin{array}{l}\text { Science \& Technology context } \\
r d G D P\end{array}$ & $\begin{array}{l}\text { R\&D expenditures as a GDP percentage } \\
\text { (average value of 2004/05/06) }\end{array}$ \\
\hline
\end{tabular}

Note: ${ }^{*}$ This variable was used only in Model 9 , where micro and small enterprises are not included in the sample.

Source: authors' construction based on e-Business Survey 2006 micro database.

According to Mueller (1967: 73), cited in Bhattacharya, Bloch (2004): “The faster a firm's sales are increasing, the more confidence it will have about its ability to secure the benefits from uncertain $R \& D$ projects, and the more patience it can afford to show in waiting for these benefits". Therefore, firms whose sales are growing are more innovative (see also Kleinknecht, Mohnen 2002). A positive sign is expected for the business growth coefficient.

The current concepts of system of innovation and open innovation emphasize the need for interconnections between organisations (namely, suppliers and customers) (Teece 1986; von Hippel 1988; Lundvall 1988). Specifically, in construction sector, working closely with suppliers (namely, to gain access to services, technologies and materials) and clients (involvement in design of construction projects) is a stimulus for innovation (Reichstein et al. 2008). 
Table 6. Descriptive statistics

\begin{tabular}{|c|c|c|c|c|}
\hline Variables & Mean & SD & Min & $\operatorname{Max}$ \\
\hline \multicolumn{5}{|l|}{ Dependent } \\
\hline Innprod (a) & 0.24 & 0.428 & 0 & 1 \\
\hline Innproce $^{(\mathrm{a})}$ & 0.26 & 0.437 & 0 & 1 \\
\hline innovPP & 0.21 & 0.410 & 0 & 1 \\
\hline \multicolumn{5}{|l|}{ Independent } \\
\hline size & 1.95 & 0.897 & 1 & 4 \\
\hline large & 0.14 & 0.348 & 0 & 1 \\
\hline mk_regional & 0.50 & 0.500 & 0 & 1 \\
\hline mk_national & 0.95 & 0.204 & 0 & 1 \\
\hline client & 0.56 & 0.496 & 0 & 1 \\
\hline supplier & 0.49 & 0.500 & 0 & 1 \\
\hline gsales & 0.57 & 0.493 & 0 & 1 \\
\hline leader & 0.66 & 0.470 & 0 & 1 \\
\hline follower & 0.47 & 0.499 & 0 & 1 \\
\hline GDPpc & 29385.31 & 12089.310 & 11481.7 & 70639.1 \\
\hline$r d G D P$ & 1.53 & 0.791 & 0.5 & 3.47 \\
\hline
\end{tabular}

Note: ${ }^{(a)}$ The mean is different from Table 3 because here missing values are excluded.

Source: Computations based on e-Business Survey 2006 micro database and Eurostat (2015a, 2015b).

As market orientation of construction firms is concerned we agree with Reichstein et al. (2008: 608-609): "the lack of exposure to a global competitive environment leaves firms less likely to adopt new products and processes. In this sense, local market orientation may be a disincentive, negatively shaping product and process innovation". See also Porter and Stern (2001).

Finally, in terms of control variables, we included a macroeconomic variable and a technological one, respectively: the Gross Domestic Product (GDP) per capita (macroeconomic context) and the domestic spending on R\&D related to GDP (\%) (Science and Technology - S\&T - context). The Gross Domestic Product (GDP) per capita intends to monitor the different national levels of economic development and the respective patterns of living standards. It is assumed that it might influence the supply and demand of construction. The percentage of domestic spending on R\&D related to GDP is a central indicator of robustness of national S\&T systems. It is a general proxy for the national propensity to innovation.

\section{Results and discussion}

The results for Model 1 (Table 7) show that the interaction with suppliers has a statistically significant positive impact on the probability of product innovation (8.4\%) and a statistically less significant role in process innovation (7.6\%). These findings differ from those obtained by Reichstein et al. (2008), who concluded that the effect is exactly the opposite, i.e., the suppliers are more relevant to the process innovation. The suppliers' role in innova- 
tion is more relevant than the clients' role. These results coincide with those of Reichstein et al. (2008) for the UK and the claims of Hall (1994). For clients (clients) no statistically significant relationship was found, which again differs from the results obtained by Reichstein et al. (2008) and Bygballe and Ingemansson (2014).

When companies want to lead the market, this has positive effects on innovation (Nam, Tatum 1997); the probability of process innovation increases by $7.3 \%$ and that of product innovation by $9.0 \%$. The size of the firm is statistically significant only for process innovation. This suggests that large firms tend to innovate more on processes than on products. Considering only product innovation, firm size presents no statistical significant effect, which is consistent with the results of the study by Reichstein et al. (2008). Another factor which also proves important for innovation in this sector is market orientation. This is statistically significant with negative effects. Companies with regional sales orientation tend to innovate less relatively to an international market orientation. The same evidence has already been found by Reichstein et al. (2008).

Table 7. Marginal effects (Model 1): product and process innovation

\begin{tabular}{|c|c|c|c|c|c|}
\hline Dependent variables & Independent variables & Marginal effects & St errors & $\mathrm{t}$ & $\mathrm{P}$ value \\
\hline \multirow{7}{*}{$\begin{array}{l}\text { Product innovation } \\
\text { (innprod) }\end{array}$} & size & 0.022 & 0.014 & 1.54 & 0.123 \\
\hline & mk_regional & -0.116 & 0.026 & -4.36 & 0.000 \\
\hline & gsales & 0.091 & 0.026 & 3.47 & 0.001 \\
\hline & follower & -0.036 & 0.029 & -1.22 & 0.222 \\
\hline & leader & 0.090 & 0.028 & 3.14 & 0.002 \\
\hline & client & 0.024 & 0.033 & 0.80 & 0.426 \\
\hline & supplier & 0.084 & 0.029 & 2.89 & 0.004 \\
\hline \multicolumn{6}{|c|}{$\mathrm{N}=1144 ;$ Pseudo $\mathrm{R}^{2}=0.0478 ; \log$ likelihood $=-643.7864 ; \mathrm{LR} \mathrm{chi}^{2}(7)=64.70$} \\
\hline \multirow{7}{*}{$\begin{array}{l}\text { Process innovation } \\
\text { (innproce) }\end{array}$} & size & 0.067 & 0.015 & 4.38 & 0.000 \\
\hline & mk_regional & -0.069 & 0.027 & -2.49 & 0.013 \\
\hline & gsales & 0.087 & 0.027 & 3.16 & 0.002 \\
\hline & follower & -0.041 & 0.030 & -1.37 & 0.172 \\
\hline & leader & 0.073 & 0.030 & 2.40 & 0.016 \\
\hline & client & 0.040 & 0.032 & 1.26 & 0.208 \\
\hline & supplier & 0.076 & 0.030 & 2.49 & 0.013 \\
\hline
\end{tabular}

Source: authors' computation based on e-Business Survey 2006 micro database.

The results obtained from other specifications are summarized in Appendix. The results do not differ substantially in Model 2 when the variable $m k$ _regional is substituted by $m k \_n a t i o n a l$. With the inclusion of additional context variables (GDPpc and $r d G D P$ ), the results did not reveal these two variables as good predictive variables of innovation in construction companies. In all the other variables, there are no significant changes in relation to a model that did not include contextual variables (Appendix). Models 5 and 6 analyze the probability of simultaneous occurrence of process and product innovation. The results show that the main predictors are suppliers, market orientation and firm size (Appendix). 
The results from Model 7 are presented in Table 8 and show that companies that innovate both in process and in product are affected in this particular behavior by the goal of being a leader in the sector (leader) and importance attached to suppliers (supplier).

The probability of innovation in process and product of the firms where the volume of business grew (gsales) - compared to those firms where sales remained constant or decreased - is $10.3 \%$ (marginal effect) for the whole sample. However, in Bhattacharya and Bloch (2004: 159) (manufacturing industry), the authors concluded that "growth is insignificant in inducing subsequent innovation". Because this analysis is cross sectional, it is not possible to identify whether the growth is a result of innovation or whether there is reverse causality.

The domestic market seems to be an obstacle to innovation in the sector compared with the international market; when companies are not oriented to the international market, preferring domestic, regional and local markets, the probability to innovate in both product and process decreases by $32.9 \%$. The firm dimension (size) is very important to joint innovation (product and process) and thus stressing the Schumpeterian hypotheses. In this Model 7 clients (clients) did not prove to be statistically significant as predictors of innovation.

Table 8. Marginal effects (Model 7): product and process innovation (joint)

Dependent variable: product and process innovation (InnovPP)

\begin{tabular}{lcccc}
\hline \multicolumn{1}{c}{ Independent variables } & Marginal effects & St errors & $\mathrm{t}$ & $\mathrm{P}$ value \\
\hline Size & 0.059 & 0.015 & 3.76 & 0.000 \\
\hline mk_national & -0.329 & 0.086 & -3.82 & 0.000 \\
\hline Gsales & 0.103 & 0.027 & 3.72 & 0.000 \\
\hline Follower & -0.040 & 0.030 & -1.32 & 0.186 \\
\hline Leader & 0.080 & 0.030 & 2.67 & 0.008 \\
\hline client & 0.032 & 0.033 & 0.96 & 0.338 \\
\hline supplier & 0.103 & 0.0321 & 3.21 & 0.001 \\
\hline $\mathrm{N}=823 ;$ Pseudo $\mathrm{R}^{2}=0.0908 ; \log$ Likelihood $=-391.88854 ; \mathrm{LR} \mathrm{chi}^{2}(7)=7827$ & \\
\hline
\end{tabular}

Source: authors' computation based on e-Business Survey 2006 micro database.

Table 9. Marginal effects (Model 8): product and process innovation (joint) (Excludes micro firms) Dependent variable: product and process innovation (InnovPP)

\begin{tabular}{lcccc}
\hline \multicolumn{1}{c}{ Independent variables } & Marginal effects & St errors & $\mathrm{t}$ & $\mathrm{P}$ value \\
\hline size & 0.123 & 0.036 & 3.39 & 0.001 \\
\hline mk_national & -0.416 & 0.113 & -3.66 & 0.000 \\
\hline gsales & 0.087 & 0.045 & 1.94 & 0.052 \\
\hline follower & -0.014 & 0.046 & -0.31 & 0.754 \\
\hline leader & 0.124 & 0.045 & 2.73 & 0.006 \\
\hline client & 0.002 & 0.052 & 0.05 & 0.963 \\
\hline supplier & 0.099 & 0.051 & 1.94 & 0.052 \\
\hline GDPpc & $-2.11 \mathrm{e}-06$ & 0.000 & -0.97 & 0.331 \\
\hline rdGDP & -0.047 & 0.030 & -1.57 & 0.117 \\
\hline
\end{tabular}

$\mathrm{N}=394 ;$ Pseudo $\mathrm{R}^{2}=0.1098 ;$ Log likehood = -200.5754; LR $\operatorname{chi}^{2}(9)=49.50$

Source: authors' computation based on e-Business Survey 2006 micro database. 
Model 8 (Table 9) excludes the micro enterprises (1-9 employees) from the sample. Business growth (gsales) and the expectation of suppliers (supplier) do not play a very relevant role for companies that innovate in both categories of innovation, contrary to what happens with the factors dimension (size) and leadership (leader), emphasizing the structural and organizational aspects of firms. As regards to the market orientation ( $m k_{-}$ national), this proves important for joint innovation, and its effect is negative. In Model 9 (Table 10), in addition to the micro enterprises (1-9 employees), small businesses (10-49 employees) are excluded. The new variables associated with size (large) and market orientation ( $m k \_$regional) show statistically significant predictive effects. When the company is large, the probability of both innovative processes increases by $35.3 \%$. With regard to market orientation, the regional market (mk_regional) limits the innovation of companies.

Table 10. Marginal effects (Model 9): process and product innovation (joint)

(Excludes micro and small firms)

Dependent variable: product and process innovation (InnovPP)

\begin{tabular}{|c|c|c|c|c|}
\hline Independent variables & Marginal effects & St errors & $\mathrm{t}$ & $\mathrm{P}$ value \\
\hline large & 0.353 & 0.113 & 3.11 & 0.002 \\
\hline mk_regional & -0.199 & 0.069 & -2.90 & 0.004 \\
\hline gsales & 0.110 & 0.073 & 1.51 & 0.130 \\
\hline follower & 0.070 & 0.072 & 0.98 & 0.328 \\
\hline leader & 0.048 & 0.076 & 0.64 & 0.522 \\
\hline client & 0.060 & 0.084 & 0.72 & 0.472 \\
\hline supplier & 0.064 & 0.085 & 0.75 & 0.450 \\
\hline$G D P p c$ & $-3.49 \mathrm{e}-06$ & 0.000 & -0.92 & 0.358 \\
\hline$r d G D P$ & 0.030 & 0.055 & 0.55 & 0.585 \\
\hline
\end{tabular}

$\mathrm{N}=189 ;$ Pseudo $\mathrm{R}^{2}=0.1389 ;$ Log likehood $=-100.34344 ; \operatorname{LR~chi}^{2}(9)=32.38$

Source: authors' computation based on e-Business Survey 2006 micro database.

\section{Conclusions and future avenues of research}

This study takes advantage of a large survey conducted in European companies - e-Business Survey (European Commission - DG Enterprise and Industry's) - which includes 14,065 firms, of which 2,654 are companies from the construction sector from 27 European countries. This research contributes to a better understanding of process innovation and product innovation in a "traditional sector" with great prominence of micro and small enterprises and identifies some of the determinants of those innovations based on Probit models. It is interesting to underline the fact that this research allowed us to analyse the dynamics of innovation in micro firms (firms with fewer than 10 employees); that it is not the case with most surveys on innovation, in particular, the Community Innovation Surveys (CIS) (see Reichstein et al. 2005, 2008; Vaona, Pianta 2008). Also, because the empirical analysis is based on micro data at firm level, it makes it possible to overcome difficulties and deficiencies on the measurement of innovation in this sector of activity, particularly 
when the adopted measure is highly aggregate such as sectorial costs of $\mathrm{R} \& \mathrm{D}$ or patents (Reichstein et al. 2008).

Most of the results converge with previous literature on innovation in this sector and the main conclusions are the following:

First, the construction sector innovates. The process innovation occurs in $25.7 \%$ of the companies and product innovation happens in $24.2 \%$. About one fifth of the industry combined the two types of innovation (product and process). Larger companies have a higher level of innovation, and there are differences by construction sub-sector. Nonetheless, the level of innovation is lower than other sectors with the exception of the Shipbuilding industry (e-Business Survey 2006).

Second, the scale of the firm affects innovation. The size of construction companies, measured through four levels in terms of number of workers (micro, small, medium and large), is important for innovation, particularly for process innovation.

Third, suppliers are very important for innovation. The results obtained either by descriptive analysis or by Probit models indicate that suppliers - i.e. the sectors that are upstream of the construction sector, such as equipment, steel, glass and cement - play a crucial role in the induction of the process and product innovation.

Fourth, the effect of customers on innovation is insufficiently known. Construction clients are either final customers, such as families, or businesses from other sectors for which the production of this sector is used as an investment good. Some studies show that clients are also important for the introduction of specific types of innovation (Reichstein et al. 2008; Fontainha 2010). However, the results obtained in this study, in contrast with the results of Lundvall $(1985,1988)$, Reichstein et al. (2008) and Bygballe, Ingemansson (2014) (the first author based on general innovations), show that the variable associated with clients does not prove relevant to innovation.

Fifth, internationalization contributes to innovation. The type of orientation of the markets (local, regional, national and international) plays an important role in innovation, and companies targeting the international market are the most innovative.

Sixth, growth and innovation are strongly associated. Firms whose sales are growing are more innovative. The probability of innovation in process and product of the firms where the volume of business grew - compared to those firms where sales remained constant or decreased - is positive ( $10 \%$, marginal effect, for the whole sample).

Seventh, there was no evidence of the influence of the context variables on innovation. The percentage of domestic spending on R\&D related to GDP (average values in the three years before the survey) have proved irrelevant in explaining innovation, which may result from the difficulty of those aggregate measures accurately reflecting microeconomic behaviours and activities. Nor was Gross Domestic Product (GDP) per capita found to be statistically significant, mostly for the same reason given for spending on R\&D as a percentage of GDP.

In general, our study confirms the construction sector as a "supplier-dominated" industry following the Pavitt's taxonomy (1984). This result is similar to those obtained in studies of innovation in the Italian and other southern European countries, where the importance of "procurement of equipment" should be stressed (Archibug et al. 1987; Barata 
2005). The determinant of product innovation and process innovation demonstrated in this study - "suppliers" - also confirms the accuracy of the Porter concept of related and support industries (clusters of construction companies, Porter 1990) in the context of the different national systems of innovation and innovation policies (Manseau, Seaden 2001).

Some future avenues of research arise from the present study: the inclusion of variables in the models representing the business context; extending the set of variables relating to sources of innovation, regulation modes, and barriers to innovation in this sector; identifying suppliers' sectors and the evaluation of the corresponding level of innovation; analysing the relationship between innovation dynamics and the economic and financial performance; testing other types of econometric models; finally, the development of a time series study that will examine the effect of innovation on construction sector growth (using panel data if available).

To conclude, we consider that the roots of important determinants of innovation lie in the seminal thesis of Schumpeter (supply side of science and technology - "suppliers") and Schmookler (market demand - "clients"). In such a context, Freeman's metaphor seems appropriate to explain the dynamics of innovation in the construction sector in Europe: "Necessity may be the mother of invention, but procreation still requires a partner" (Freeman 1982: 110).

\section{References}

Ahuja, G.; Lampert, C.; Tandon, V. 2008. Moving beyond schumpeter: management research on the determinants of technological innovation, The Academy of Management Annals 2(1): 1-98.

https://doi.org/10.1080/19416520802211446

Archibug, D.; Cesaratto, S.; Sirilli, G. 1987. Innovative activity, R\&D and patenting: the evidence of the survey on innovation diffusion in Italy, STI Review 2: 135-150 [online], [cited 28 October 2012]. Available from Internet: http://www.oecd-ilibrary.org/science-and-technology/sti-sciencetechnology-and-industry-review_16097637

Arora, S. K.; Foley, R. W.; Youtie, J.; Shapira, P.; Wiek, A. 2014. Drivers of technology adoption - the case of nanomaterials in building construction, Technological Forecasting and Social Change 87: 232-244. https://doi.org/10.1016/j.techfore.2013.12.017

Barata, J. M. 2005. Innovation in the Portuguese manufacturing industry: analysis of a longitudinal company panel, International Advances in Economic Research 11(3): 301-314. https://doi.org/10.1007/s11294-005-6659-5

Barrett, P.; Sexton, M. 2006. Innovation in small, project-based construction firms, British Journal of Management 17(4): 331-346. https://doi.org/10.1111/j.1467-8551.2005.00461.x

Becker, W.; Dietz, J. 2004. R\&D cooperation and innovation activities of firms. Evidence for the German manufacturing industry, Research Policy 33(2): 209-223.

https://doi.org/10.1016/j.respol.2003.07.003

Bhattacharya, M.; Bloch, H. 2004. Determinants of innovation, Small Business Economics 22(2): 155162. https://doi.org/10.1023/B:SBEJ.0000014453.94445.de

Bogers, M.; Lhuillery, S. 2011. A functional perspective on learning and innovation: investigating the organization of absorptive capacity, Industry and Innovation 18(6): 581-610.

https://doi.org/10.1080/13662716.2011.591972 
Bontempi, M. E.; Mairesse, J. 2015. Intangible capital and productivity at the firm level: a panel data assessment, Economics of Innovation and New Technology 24(1-2): 22-51. https://doi.org/10.1080/10438599.2014.897859

Bowley, M. 1960. Innovation in building material. London: Gerald Duckworth.

Brochner, J. 2010. Construction contractors as service innovators, Building Research \& Information 38(3): 235-246 https://doi.org/10.1080/09613211003616706

Bygballe, L. E.; Ingemansson, M. 2014. The logic of innovation in construction, Industrial Marketing Management 43(3): 512-524. https://doi.org/10.1016/j.indmarman.2013.12.019

Chesbrough, H. 2003. Open innovation: the new imperative for creating and profiting from technology. Boston: MA: Harvard School Press.

Damanpour, F. 2010. An integration of research findings of effects of firm size and market competition on product and process innovations, British Journal of Management 21(4): 996-1010. https://doi.org/10.1111/j.1467-8551.2009.00628.x

De Place Hansen, E. J.; Larsen, J. N. 2011. Employment and winter construction: a comparative analysis of Denmark and western European countries with a similar climate, Construction Management and Economics 29(9): 875-890. https://doi.org/10.1080/01446193.2011.617762

D'Este, P.; Guy, F.; Iammarino, S. 2012. Shaping the formation of university-industry research collaborations: what type of proximity does really matter?, Journal of Economic Geography 13(4): 537-558. https://doi.org/10.1093/jeg/lbs010

Dodgson, M.; Gann, D. M.; Phillips, N. (Eds.). 2014. The Oxford handbook of innovation management. Oxford, UK: Oxford University Press. https://doi.org/10.1093/oxfordhb/9780199694945.001.0001

European Commission. 2003. Enterprise and industry: small and medium-sized enterprises [online], [cited 28 October 2012]. Available from Internet: http://ec.europa.eu

European Commission. 2006. The e-Business Survey 2006-Methodology Report [online], [cited 28 October 2012]. Available from Internet: www.ebusiness-watch.org

European Commission. 2012a. High-tech statistics [online], [cited 28 October 2012]. Available from Internet: http://epp.eurostat.ec.europa.eu

European Commission. 2012b. Sustainable Competitiveness of the Construction Sector. FWC Sector Competitiveness Studies $N^{\circ}$ B1/ENTR/06/054. Final report [online], [cited 24 April 2013]. Available from Internet: http://ec.europa.eu

European Commission. 2012c. Industry and construction statistics [online], [cited 19 August 2012]. Available from Internet: http://epp.eurostat.ec.europa.eu

Eurostat. 2015a. GDP and main components [online], [cited 10 January 2015]. Available from Internet: http://appsso.eurostat.ec.europa.eu/nui/show.do

Eurostat. 2015b. Annual detailed enterprise statistics for construction [online], [cited 10 January 2015]. Available from Internet: http://appsso.eurostat.ec.europa.eu/nui/submitViewTableAction.do

Fontainha, E. 2010. The determinants of ERP, SCM and CRM systems in European firms, in J. Q. Varajão, M. Cruz-Cunha, G. D. Putnik, A. Trigo (Eds.). Enterprise information systems, Part I. Heidelberg: Springer-Verlag, 147-150. https://doi.org/10.1007/978-3-642-16402-6_16

Fontainha, E.; Martins, J. T. ; Vasconcelos, A. C. 2014. Exploring the determinants of PAS, EDMS, and PACS adoption in European hospitals, Procedia Technology 16: 1502-1509. https://doi.org/10.1016/j.protcy.2014.10.171

Freeman, C. 1982. The economics of industrial innovation. Oxford: Frances Pinter.

Freeman, C.; Soete, L. 1997. The economics of industrial innovation. London, United Kingdom: Pinter Publishers.

Gambatese, J.; Hallowell, M. 2011. Enabling and measuring innovation in the construction industry, Construction Management and Economics 29(6): 553-567.

https://doi.org/10.1080/01446193.2011.570357 
Gann, D. M.; Wang, Y.; Hawkins, R. 1998. Do regulations encourage innovation? The case of construction organizations, Building Research \& Information 26(5): 280-296. https://doi.org/10.1080/096132198369760

Gault, F. (Ed.). 2013. Handbook of innovation indicators and measurement. Cheltenham, UK: Edward Elgar. https://doi.org/10.4337/9780857933652

Gramlich, E. M. 1994. Infrastructure investment: a review essay, Journal of Economic Literature 32: 1176-1196.

Hall, P. 1994. Innovation, economics and evolution. New York, Sydney: Harvester wheatsheaf.

Hansen, T.; Winther, L. 2011. Innovation, regional development and relations between high- and lowtech industries, European Urban and Regional Studies 18(3): 321-339.

https://doi.org/10.1177/0969776411403990

Hartmann, A. 2006. The context of innovation management in construction firms, Construction Management and Economics 24(6): 567-578. https://doi.org/10.1080/01446190600790629

Kaklauskas, A.; Kelpsiene, L.; Zavadskas, E. K.; Bardauskiene, D.; Kaklauskas, G.; Urbonas M.; Sorakas, V. 2011. Crisis management in construction and real estate: conceptual modeling at the micro-, meso- and macro-levels, Land Use Policy 28(1): 280-293. https://doi.org/10.1016/j.landusepol.2010.06.008

Kleinknecht, A.; Mohnen, P. (Eds.). 2002. Innovation and firm performance. Econometric explorations of survey data. Basingstoke, UK: Palgrave. https://doi.org/10.1057/9780230595880

Kline, S. J.; Rosenberg, N. 1986. An overview of innovation, in R. Landau, N. Rosenberg (Eds). The positive sum strategy: harnessing technology for economic development. Washington, DC: National Academy Press, 275-305.

Lasagni, A. 2012. How can external relationships enhance innovation in SMEs? New evidence for Europe, Journal of Small Business Management 50(2): 310-339.

https://doi.org/10.1111/j.1540-627X.2012.00355.x

Loosemore, M. 2014. Innovate or Perish? Exploring some of the myths of construction innovation, Australasian Journal of Construction Economics and Building-Conference Series 2(2): 44-55.

Lundvall, B. A. 1985. Product innovation and user-producer interaction. Aalborg: Aalborg University Press.

Lundvall, B. A. 1988. Innovation as an interactive process-from user-producer interaction to national systems of innovation, in G. Dosi, C. Freeman, R. Nelson, G. Silverberg, L. Soete (Eds.). Technical Change and Economic Theory. London: Pinter.

Malecki, E.; Tootle, D. 1996. The role of networks in small firm competitiveness, International Journal of Technology Management, 11(1-2): 43-57.

Manseau, A.; Seaden, G. (Eds.). 2001. Innovation in construction: an international review of public policies. London, UK: Taylor \& Francis.

Marques, C.; Barata, J. M. 2006. Determinants of the innovation process: an empirical test for the Portuguese manufacturing industry, Management Research: The Journal of the Iberoamerican Academy of Management 4(2): 113-126. https://doi.org/10.2753/JMR1536-5433040203

Mueller, D. C. 1967. The firm decision process: an econometric investigation, The Quarterly Journal of Economics 81(1): 58-87. https://doi.org/10.2307/1879673

Nam, C.; Tatum, C. 1988. Major characteristics of constructed products and resulting limitation of construction technology, Construction Management and Economics 6(2): 133-148. https://doi.org/10.1080/01446198800000012

Nam, C.; Tatum, C. 1997. Leaders and champions for construction innovation, Construction Management and Economics 15(3): 259-270. https://doi.org/10.1080/01446198800000012

Noailly, J. 2012. Improving the energy efficiency of buildings: the impact of environmental policy on technological innovation, Energy Economics 34(3): 795-806.

https://doi.org/10.1016/j.eneco.2011.07.015 
OECD. 2005. Oslo manual: guidelines for collecting and interpreting technological innovation. 3rd ed. OECD: OECD.

Paulson, B. 1995. Computer applications in construction. New York: McGraw-Hill.

Pavitt, K. 1984. Sectoral patterns of technical change: towards taxonomy and a theory, Research Policy 13(4): 343-373. https://doi.org/10.1016/0048-7333(84)90018-0

Pavitt, K. 2002. Innovating routines in the business firm: what corporate tasks should they be accomplishing?, Industrial and Corporate Change 11(1): 117-133. https://doi.org/10.1093/icc/11.1.117

Porter, M. E. 1990. The competitive advantage of nations. London: MacMillan Press. https://doi.org/10.1007/978-1-349-11336-1

Porter, M. E.; Stern, S. 2001. Innovation: location matters, MIT Sloan Management Review 42(4): 28-36.

Reichstein, T.; Salter, A.; Gann, D. M. 2005. Last among equals: a comparison of innovation in construction, services and manufacturing in the UK, Construction Management and Economics 23(6): 1145-1166. https://doi.org/10.1080/01446190500126940

Reichstein, T.; Salter, A.; Gann, D. M. 2008. Break on through: sources and determinants of product and process innovation among UK construction firms, Industry \& Innovation 15(6): 601-625. https://doi.org/10.1080/13662710802565198

Rothwell, R. 1992a. Developments towards the fifth generation model of innovation, Technology Analysis \& Strategic Management 1(4): 73-75. https://doi.org/10.1080/09537329208524080

Rothwell, R. 1992b. Successful industrial innovation: critical factors for the 1990s, R\&D Management 22(3): 221-239. https://doi.org/10.1111/j.1467-9310.1992.tb00812.x

Salter, A.; Alexy, O. 2014. The nature of Innovation, in M. Dodgson, D. M. Gann, N. Phillips (Eds.). 2014. The Oxford handbook of innovation management. Oxford, UK: Oxford University Press, 26-52.

Sampson, R. 2007. R\&D alliances and firm performance: the impact of technological diversity and alliance organization on innovation, Academy of Management Journal 50(2): 364-386. https://doi.org/10.5465/AMJ.2007.24634443

Schmookler, J. 1966. Invention and economic growth. Cambridge, MA: Harvard University Press. https://doi.org/10.4159/harvard.9780674432833

Schumpeter, J. 1942. Capitalism, socialism, and democracy. New York: Harper \& Brothers.

Silverberg, G.; Soete, L. 1994. The economics of growth and technical change. USA: Edward Elgar.

Skibniewski, M. J.; Zavadskas, E. K. 2013. Technology development in construction: a continuum from distant past into the future, Journal of Civil Engineering and Management 19(1): 136-147. https://doi.org/10.3846/13923730.2012.756060

Spithoven, A.; Clarysse, B.; Knockaert, M. 2011. Building absorptive capacity to organise inbound open innovation in traditional industries, Technovation 31(1): 10-21. https://doi.org/10.1016/j.technovation.2009.08.004

Teece, D. J. 1986. Profiting from technological innovation-implications for integration, collaboration, licensing and public-policy, Research Policy 15(6): 285-305. https://doi.org/10.1016/0048-7333(86)90027-2

Testa, F.; Iraldo, F.; Frey, M. 2011. The effect of environmental regulation on firm's competitive performance: the case of the building \& construction sector in some EU regions, Journal of Environmental Management 92(9): 2136-2144. https://doi.org/10.1016/j.jenvman.2011.03.039

Tykka, S.; McCluskey, D.; Nord, T.; Ollonqvist, P.; Hugosson, M.; Roos, A.; Ukrainski, K.; Nyrud, A. Q.; Bajric, F. 2010. Development of timber framed firms in the construction sector - is EU policy one source of their innovation?, Forest Policy and Economics 12(3): 199-206.

https://doi.org/10.1016/j.forpol.2009.10.003 
Vaona, A.; Pianta, M. 2008. Firm Size and Innovation in European Manufacturing, Small Business Economics 30(3): 283-299. https://doi.org/10.1007/s11187-006-9043-9

Zavadskas, E. K.; Kaklauskas, A.; Banaitis, A. 2011. The use of the intelligent library and tutoring system at all stages of a building life cycle, Inzinerine Ekonomika-Engineering Economics 22(1): 14-23. https://doi.org/10.5755/j01.ee.22.1.214

Zavadskas, E. K.; Vilutiene, T.; Turskis, Z.; Šaparauskas, J. 2014. Multi-criteria analysis of Projects' performance in construction, Archives of Civil and Mechanical Engineering 14(1): 114-121. https://doi.org/10.1016/j.acme.2013.07.006

Zutshi, A.; Creed, A. 2015. An international review of environmental initiatives in the construction sector, Journal of Cleaner Production 98: 92-106. https://doi.org/10.1016/j.jclepro.2014.06.077

\section{APPENDIX}

\section{Determinants of product and process innovation (models)}

\section{Model 1}

innprod $=\beta 0+\beta 1$ size $+\beta 2 m k \_$regional $+\beta 3$ gsales $+\beta 4$ follower $+\beta 5$ leader $+\beta 6$ client + $\beta 7$ supplier $+u$;

innproce $=\beta 0+\beta 1$ size $+\beta 2 m k \_$regional $+\beta 3$ gsales $+\beta 4$ follower $+\beta 5$ leader $+\beta 6$ client + $\beta 7$ supplier $+u$.

\section{Model 2}

innprod $=\beta 0+\beta 1$ size $+\beta 2 m k \_n a t i o n a l+\beta 3$ gsales $+\beta 4$ follower $+\beta 5$ leader $+\beta 6$ client + $\beta 7$ supplier $+u$;

innproce $=\beta 0+\beta 1$ size $+\beta 2 m k \_$national $+\beta 3$ gsales $+\beta 4$ follower $+\beta 5$ leader $+\beta 6$ client + $\beta 7$ supplier $+u$.

\section{Model 3}

innprod $=\beta 0+\beta 1$ size $+\beta 2 m k \_$regional $+\beta 3$ gsales $+\beta 4$ follower $+\beta 5$ leader $+\beta 6$ client + $\beta 7$ supplier $+\beta 8 G D P p c+\beta 9 r d G D P+u$;

innproce $=\beta 0+\beta 1$ size $+\beta 2$ mk_regional $+\beta 3$ gsales $+\beta 4$ follower $+\beta 5$ leader $+\beta 6$ client + $\beta 7$ supplier $+\beta 8 G D P p c+\beta 9 r d G D P+u$.

\section{Model 4}

innprod $=\beta 0+\beta 1$ size $+\beta 2 m k \_n a t i o n a l+\beta 3$ gsales $+\beta 4$ follower $+\beta 5$ leader $+\beta 6$ client + $\beta 7$ supplier $+\beta 8 G D P p c+\beta 9 r d G D P+u$;

innproce $=\beta 0+\beta 1$ size $+\beta 2 m k \_$national $+\beta 3$ gsales $+\beta 4$ follower $+\beta 5$ leader $+\beta 6$ client + $\beta 7$ supplier $+\beta 8 G D P p c+\beta 9 r d G D P+u$.

Models 5, 6 and 7 (the dependent variable is both product and process innovation).

Models 8 and 9 (applied to subsamples related to firm size, Model 9 include variable large instead of size). 


\section{Determinants of innovation models (marginal effects after probit)}

\begin{tabular}{|c|c|c|c|c|c|c|c|c|}
\hline & 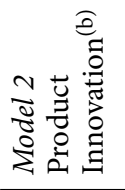 & 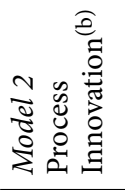 & 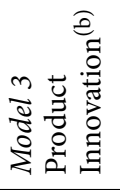 & 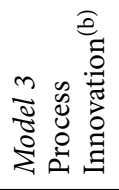 & 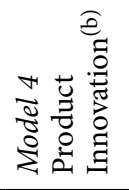 & 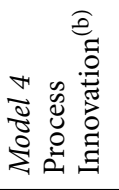 & 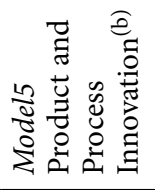 & 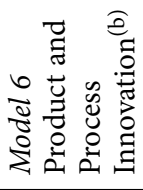 \\
\hline size & & + & & + & & + & & + \\
\hline mk_regional & (a) & (a) & - & & (a) & (a) & - & - \\
\hline mk_national & - & & (a) & (a) & - & & (a) & (a) \\
\hline gsales & & + & + & + & + & + & + & + \\
\hline \multicolumn{9}{|l|}{ follower } \\
\hline leader & + & + & + & + & + & + & + & \\
\hline \multicolumn{9}{|l|}{ client } \\
\hline supplier & & & + & + & + & + & + & + \\
\hline$G D P p c$ & (a) & (a) & & & & & & (a) \\
\hline$r d G D P$ & (a) & (a) & & & & & & (a) \\
\hline N Obs. & 1144 & 1146 & 900 & 903 & 900 & 903 & 900 & 823 \\
\hline Pseudo R2 & 0.0364 & 0.0418 & 0.0660 & 0.0709 & 0.0792 & 0.0689 & 0.0657 & 0.0880 \\
\hline
\end{tabular}

Notes: (a) Variable not included in the model; (b) Marginal Effect (Positive = “+”; Negative = "-”). The table only shows the Marginal Effects with $\mathrm{p}<0.010$.

José M. BARATA. PhD in Economics. Assistant Professor. Department of Economics. ISEG Lisbon School of Economics and Management. Universidade de Lisboa, Portugal. First degree in Economics, ISE Technical University of Lisbon (1981). Master of Economics (1988). Doctor (1996). Assistant Professor of Economics, R\&D Management and Industrial Organization at ISEG Lisbon School of Business and Administration, Universidade de Lisboa, Portugal. He has been Coordinator of Graduate and PostGraduate courses at the Portuguese School of Banking Management (Portuguese Banking Association). Research interests: innovation management, R\&D management and management information systems for the financial industry. He holds a PhD in Economics (UTL).

Elsa FONTAINHA. PhD in Economics, Assistant Professor. Department of Economics. ISEG Lisbon School of Economics and Management. Universidade de Lisboa, Portugal. First degree in Economics, ISE Technical University of Lisbon (1979). Master of Economics (1988). Doctor (1997). Distinguish Scholarships Scheme (2013) from the Information School of University of Sheffield (UK). Research visits to the University of Sheffield, UK $(2016,2013)$, Université Libre de Bruxelles, Belgium (2014), Northumbria University, Newcastle, UK (2009 and 2011). Sabbatical Leave in Saint Mary's University, Halifax, Canada (2005). Currently she is the Team Leader at ISEG of the European Community Project Horizon2020, PLOTINA (2016-2020; Ref.666008). Large experience of participation in international projects. Scholarly articles (Information Research, Library High Tech, eLearning Papers, Review of Economics of the Household, Procedia Technology, etc.) and books (Learning and Instruction in the Digital Age, Enterprise Information Systems, Information Systems and Technologies, Encyclopedia of Quality of Life and Well-Being Research,etc.). Research Interests: firm behavior and household economics and finance. 